\title{
Monitoring Kapasitas Baterai dan Kecepatan Laju Skuter Listrik Berbasis Android
}

\section{Muhammad Faizal Fernandito Sugianto*, Miftachul Ulum, Achmad Fiqhi Ibadillah}

Teknik Elektro Universitas Trunojoyo Madura, Jalan Raya Telang, Kabupaten Bangkalan 69162, Indonesia

*mfaizal6@gmail.com

Kata Kunci :

Kendaraan

Baterai

Skuter

Android

Kecepatan

\section{ABSTRAK}

Kendaraan yang digunakan manusia pada umumnya masih menggunakan bahan bakar fosil. Namun kendaraan tersebut memiliki efek samping yaitu memiliki emisi yang menjadi polutan bagi lingkungan. Oleh karena itu, mulai digalakkan penggunaan kendaraan yang berbahan bakar ramah lingkungan. Skuter elektrik merupakan salah satu jenis dari kendaraan elektrik yang sering digunakan oleh masyarakat. Skuter elektrik menggunakan baterai sebagai sumber energi penggeraknya. Berdasarkan masalah tersebut dibuatlah rancang bangun monitoring kapasitas baterai dan kecepatan skuter elektrik berbasis android untuk dapat mengambil data yang digunakan untuk menganalisa pengaruh kapasitas baterai terhadap jarak tempuh skuter. Pada penelitian ini sistem yang dibuat ialah sistem yang dapat menampilkan presentasi baterai dan kecepatan pada skuter elektrik. Digunakan sensor IR untuk mendeteksi kecepatan pada skuter, ADC untuk menampilkan kapasitas baterai, Bluetooth untuk mengirim data pada android, LCD untuk menampilkan data dan android untuk memonitoring data. Setelah melakukan pengujian sistem yang dibuat dapat menunjukkan persentase baterai perentase baterai oleh data ADC, data sensor infra merah menjadi $\mathrm{Km} / \mathrm{jam}$, dan data tersebut dapat diampilkan pada LCD lalu dikirim bluetooth ke android. Pada pengujian sistem ini dapat disimpulkan bahwa semakin berat pengguna skuter maka jarak yang ditempuh akan semakin pendek.

Vehicles used by humans generally still use fossil fuels. However, these vehicles have the side effect of having emissions that become pollutants for the environment. Therefore, the use of vehicles that run on environmentally friendly fuels has begun to be encouraged. Electric scooters are one type of electric vehicle that is often used by the public. Electric scooters use batteries as the energy source to drive them. Based on this problem, an Android-based battery capacity and speed monitoring design was made to be able to retrieve the data used to analyze the effect of battery capacity on the distance 
traveled by the scooter. In this study, the system created is a system that can display battery and speed presentations on an electric scooter. IR sensors are used to detect speed on the scooter, ADC to display battery capacity, Bluetooth to send data to android, LCD to display data and android to monitor data. After testing the system that is made to show the battery percentage per battery percentage by $A D C$ data, infrared sensor data becomes Km / hour, and the data can be displayed on the LCD and then sent by bluetooth to Android. In testing this system it can be concluded that the heavier the scooter user, the shorter the distance traveled.

\section{Pendahuluan}

Penulisan teks Kendaraan yang digunakan manusia pada umumnya dewasa ini masih menggunakan bahan bakar fosil. Namun kendaraan tersebut memiliki efek samping yaitu memiliki emisi yang menjadi polutan bagi lingkungan. Oleh karena itu, mulai digalakkan penggunaan kendaraan yang berbahan bakar ramah lingkungan. Salah satunya adalah kendaraan elektrik seperti skuter listrik. Skuter listrik merupakan salah satu jenis dari kendaraan elektrik yang sering digunakan oleh masyarakat. Skuter listrik merupakan kendaraan ringan yang memiliki jangkauan jarak tempuh yang tidak terlalu luas, namun sangat ringkas dan sederhana. Skuter listrik menggunakan baterai sebagai sumber energi penggeraknya. Performa skuter listrik yang meliputi jarak tempuh maksimal dan durasi pemakaian sangat dipengaruhi oleh baterai yang digunakan. Berdasarkan masalah tersebut dibuatlah rancang bangun monitoring kapasitas baterai dan kecepatan skuter listrik berbasis android untuk dapat mengambil data yang digunakan untuk menganalisa pengaruh kapasitas baterai terhadap jarak tempuh skuter.

\section{Perancangan Sistem}

Pada penelitihan ini sistem yang dibuat ialah sistem yang dapat menampilkan presentasi baterai dan kecepatan pada skuter listrik. Digunakan sensor IR untuk mendeteksi kecepatan pada skuter, ADC untuk menampilkan kapasitas baterai, Bluetooth untuk mengirim data pada android, LCD untuk menampilkan data dan android untuk memonitoring data. Pembuatan rancangan sistem pada alat ini terdiri dari perancangan perangkat keras (hardware) dan perancangan perangkat lunak (software).

\subsection{Blok Diagram Sistem}




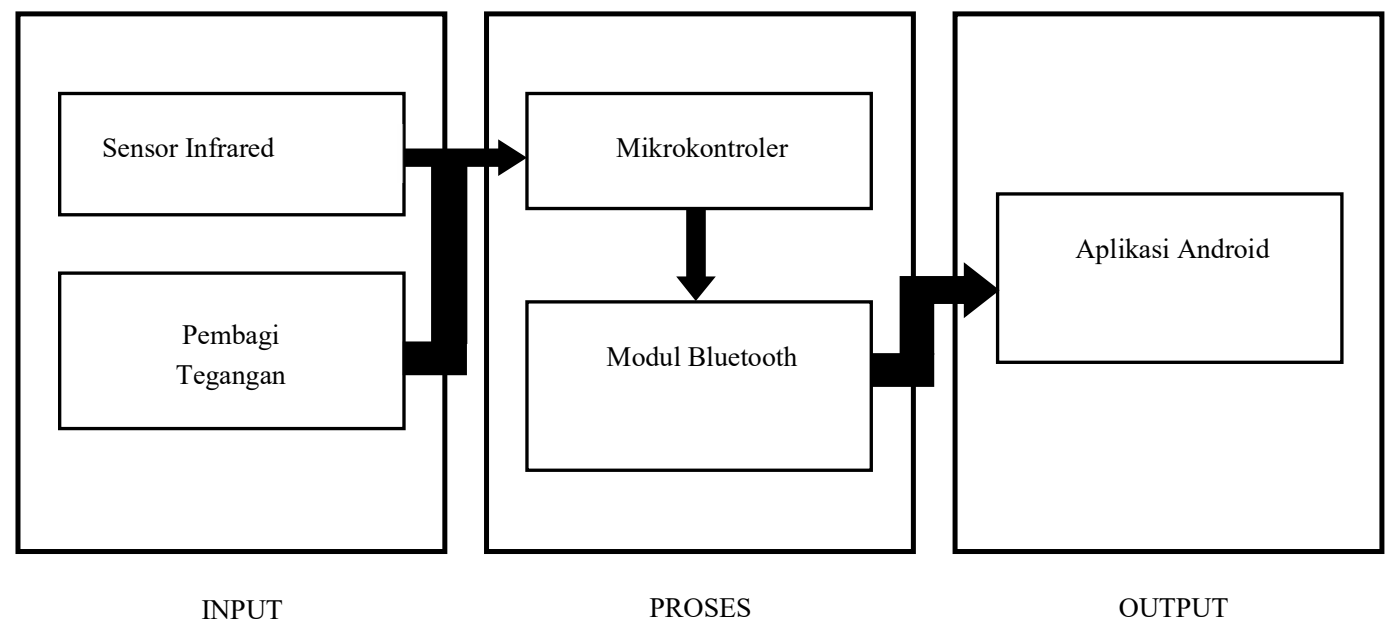

Gambar 1 Blok Diagram Sistem

Pada gambar diatas adalah gambaran keseluruan sistem, dapat dijelaskan bahwa baterai digunakan untuk sumber energi skuter dan perangkat mikrokontroler. untuk mengetahui nilai baterai digunakan sensor pembagi tengangan. sensor inframerah berfungsi sebagai alat ukur kecepatan, sensor yang digunakan adalah sensor infrared LM 393. Perangkat mikrokontroler berfungsi sebagai pengola data sensor menjadi nilai tegangan dan kecepatan, sehingga dapat ditampilkan pada perangkat modul LCD 16x2. Data kecepatan dan tegangan dikirim melalui modul bluetooth untuk di tampilkan pada perangkat android.

\subsection{Kebutuhan Sistem}

Tabel 1 Kebutuhan

\begin{tabular}{lcl}
\hline Nama perangkat atau komponen & Jumlah & Kegunaan \\
\hline Sensor tegangan (pembag tegangan) & 1 & mengetahui nilai tegangan baterai \\
Sensor inframerah & 1 & mengetahui kecepatan skuter \\
Baterai skuter & 1 & supply skuter dan mikrokontroler \\
Mikrokontroler atmega 16 & 1 & mengolah data sensor \\
Modul bluetooth hc05 & 1 & mengirim data ke GUI android \\
Lcd 16x2 & 1 & menampilkan data \\
GUI android & 1 & monitoring baterai dan kecepatan \\
\hline
\end{tabular}

1. Sensor inframerah

Sensor inframerah merupakan salah satu komponen elektronika yang mampu mengenali sinar cahaya inframerah. Sensor ini memiliki sistem yang menggunakan sinar inframerah sebagai media receiver dan transmitter. Sensor akan bekerja mengenali, apabila sinar inframerah yang dipancarkan tertutupi oleh suatu benda yang membuat sinar inframerah tersebut tidak mampu terdeteksi oleh receiver. 


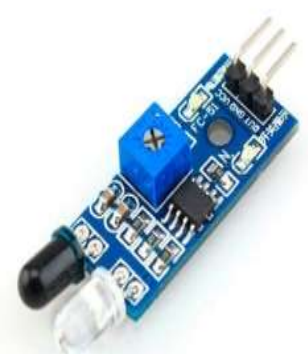

Gambar 2 Sensor inframerah

\section{Modul bluetooth}

Modul bluetooth adalah salah satu komponen yang diperlukan sebagai bahan tambahan pada board mikrokontroler seperti arduino. Modul bluetooth ini bekerja pada frekuensi 2,4 GHz dan mampu melakukan komunikasi nirkabel secara master-slave dengan jarak maksimal 15 meter

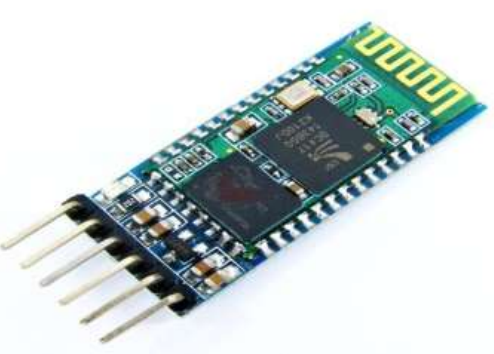

Gambar 3 Modul bluetooth

3. LCD

LCD adalah salah satu media elektronika yang mampu menampilakan data yang kita inginkan. LCD menggunakan kristal cair untuk menampilkan tampilan utamanya.

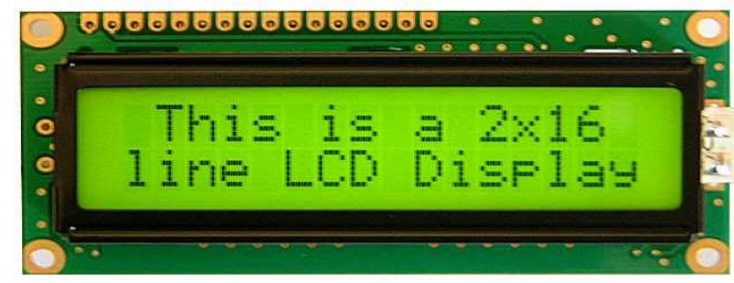

Gambar 4 LCD $2 \times 16$

4. Skuer listrik

Skuter listrik yang bermerk taffsport digerakan dengan tenaga listrik. Skter ini termasuk ramah lingkungan karena tidak memproduksi asap maupun suara bising seperti kendaraan bermotor lainnya. Kecepatan skuter listrik ini berkisar $20 \mathrm{~km} / \mathrm{jam}$. Dengan memiliki berat rata-rata antara 7-40 kg, skuer ini bisa diberikan beban hingga berat $100 \mathrm{Kg}$. 


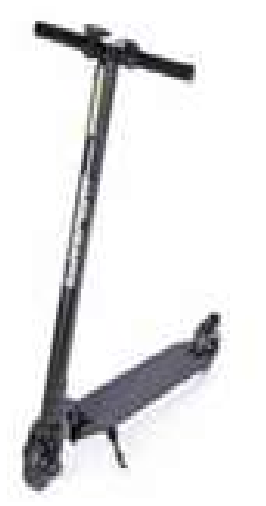

\section{Gambar 5 Skuter listrik}

5. Pembagi tegangan

Pembagi Tegangan berfungsi untuk menurunkan tegangan hingga dibawah 5V untuk dibaca melalui Pin ADC. Tegangan dari baterai adalah sebesar 0-30 volt. Sehingga untuk mengetahui tegangannya melalui mikrokontroler, tegangan perlu diturunkan. Berikut adalah rangkaian pembagi tegangan yang digunakan seperti pada gambar di bawah

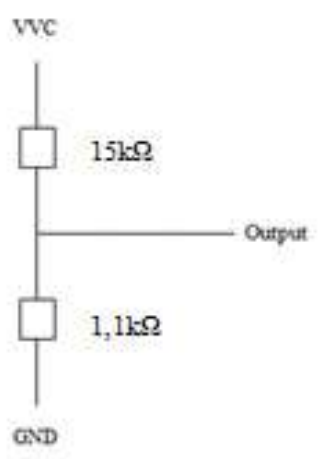

\section{Gambar 6 Rangkaian pembagi tegangan}

Jika tegangan input 0 - 30 volt, maka tegangan output dapat dihitung dengan perhitungan berikut

$$
\text { Vout }=\frac{R 2}{R 1+R 2} \times \text { Vin }
$$

Keterangan:

Vin $=$ Tegangan input dari baterai skuter listrik

$\mathrm{R} 1=$ resistor senilai $15 \mathrm{~K} \Omega$

$\mathrm{R} 2=$ resistor senilai $1,1 \mathrm{~K} \Omega$

- $\mathrm{Vin}=30 \mathrm{~V}$

$$
\begin{aligned}
\text { Vout } & =\frac{1,1 K \Omega}{15 K \Omega+1,1 K \Omega} \times 30 \mathrm{~V} \\
& =2,04 \mathrm{~V}
\end{aligned}
$$

- $\mathrm{Vin}=15 \mathrm{~V}$ 


$$
\begin{aligned}
\text { Vout } & =\frac{1,1 K \Omega}{15 K \Omega+1,1 K \Omega} \times 15 \mathrm{~V} \\
& =1,02 \mathrm{~V}
\end{aligned}
$$

- $\operatorname{Vin}=0 \mathrm{~V}$

$$
\begin{aligned}
\text { Vout } & =\frac{1,1 K \Omega}{15 K \Omega+1,1 K \Omega} \times 0 \mathrm{~V} \\
& =0 \mathrm{~V}
\end{aligned}
$$

\subsection{Pengujian Alat}

1. Pengujian pembacaan LCD

Pengujian pembacaan lcd dilakukan dengan cara memberikan suatu masukan karakter dan lcd dikatakan berhasil bila lcd dapat menampilkan suatu karakter yang sama seperti yang diberikan.

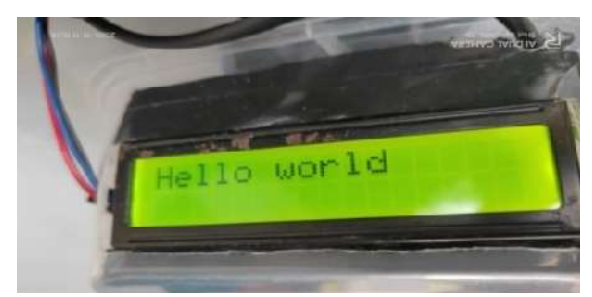

Gambar. 6 Tampilan LCD

2. Pengujian sensor inframerah

Pengujian sensor inframerah yaitu dengan cara sensor inframerah membaca nilai RPM dan ditampilkan pada LCD.

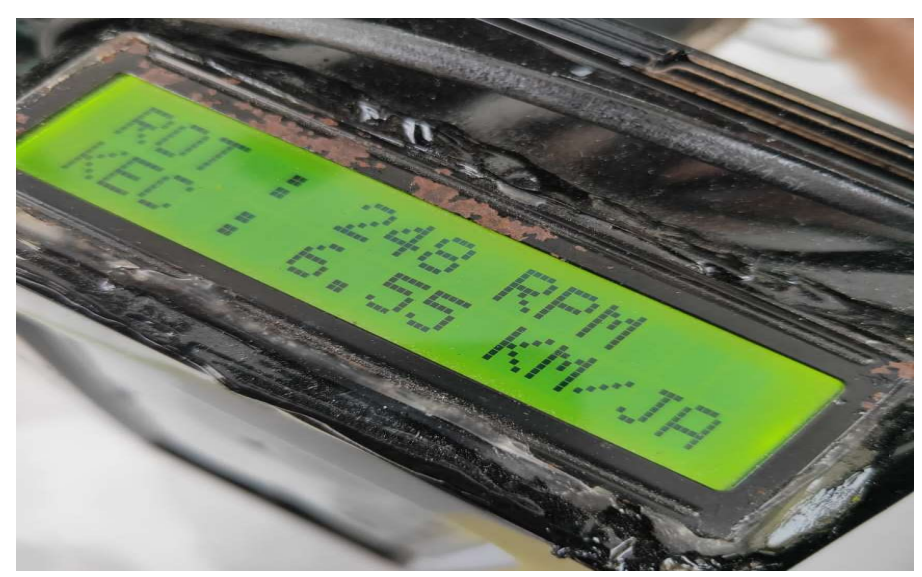

Gambar. 7 Tampilan pengujian sensor inframerah

Tabel 2 - Tabel pengujian sensor inframerah

\begin{tabular}{lll}
\hline No & RPM & Km/jam \\
\hline 1 & 248 & $6,55 \mathrm{Km} /$ jam \\
2 & 265 & $7,00 \mathrm{Km} /$ jam \\
3 & 281 & $7,42 \mathrm{Km} /$ jam \\
4 & 361 & $9,53 \mathrm{Km} /$ jam \\
5 & 225 & $5,94 \mathrm{Km} /$ jam \\
\hline
\end{tabular}


Rumus kecepatan

$$
v=\frac{R p m \times K \cdot r o d a \times 10^{-5}}{1 / 60}
$$

Keterangan:

Keliling roda $=44 \mathrm{~cm}, \mathrm{r}=7 \mathrm{~cm}$

Menit ke jam $=1 / 60$

$10^{-5}=$ konversi $\mathrm{cm} \mathrm{ke} \mathrm{km}$

Contoh salah satu perhitungan kecepatan

$$
\begin{aligned}
v & =\frac{248 \times 44 \times 10^{-5}}{1 / 60} \\
v & =\frac{248 \times 44 \times 60}{10^{5}} \\
& =6,55 \mathrm{~km} / \mathrm{jam}
\end{aligned}
$$

3. Pengujian pembacaan ADC

Pengujian ADC dilakukan dengan cara memberikan suatu inputan nilai dan dikatakan berhasil bila ADC dapat membaca nilai yang diberikan dan di tampilkan pada LCD.

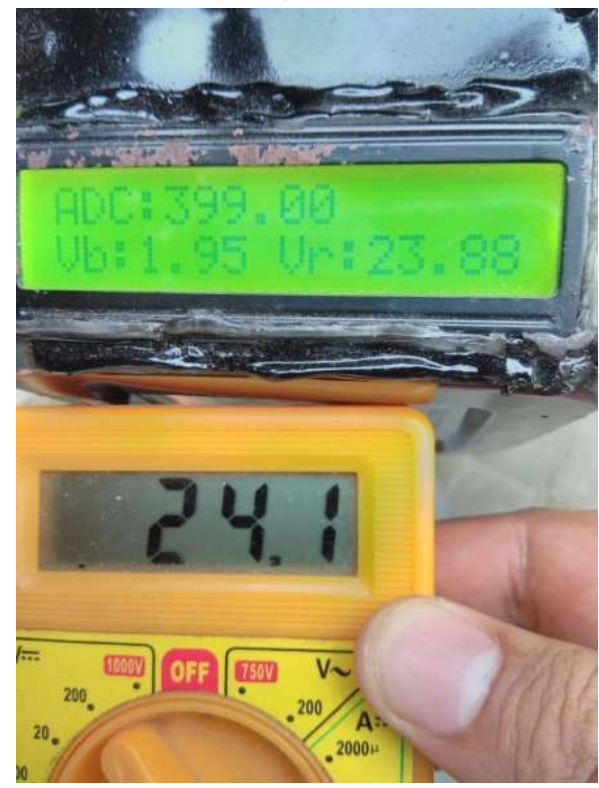

Gambar. 8 Tampilan pengujian ADC

\begin{tabular}{ccccc}
\hline No & ADC & $\begin{array}{c}\text { Tabel 3 - Tabel percobaan ADC } \\
\text { Tegangan } \\
\text { terbaca }\end{array}$ & $\begin{array}{c}\text { Tegangan } \\
\text { real }\end{array}$ & $\begin{array}{c}\text { Tegangan real } \\
\text { (AVO) }\end{array}$ \\
\hline 1 & 417 & $2.03 \mathrm{~V}$ & $24,96 \mathrm{~V}$ & $25,2 \mathrm{~V}$ \\
2 & 399 & $1,95 \mathrm{~V}$ & $23,88 \mathrm{~V}$ & $24,1 \mathrm{~V}$ \\
3 & 377 & $1,84 \mathrm{~V}$ & $22,56 \mathrm{~V}$ & $22,5 \mathrm{~V}$ \\
4 & 408 & $1,99 \mathrm{~V}$ & $24,42 \mathrm{~V}$ & $24,6 \mathrm{~V}$ \\
5 & 425 & $2,07 \mathrm{~V}$ & $25,44 \mathrm{~V}$ & $24,3 \mathrm{~V}$ \\
\hline
\end{tabular}




\subsection{Pengujian Keseluruhan Sistem}

Pengujian pada tahap ini yaitu hasil pembacaan data ADC dikonversikan menjadi voltage volt dan dikonversikan lagi menjadi persenase baterai, hasil pembacaan data sensor inframerah yaitu rpm di konesikan menjadi $\mathrm{Km} / \mathrm{jam}$.

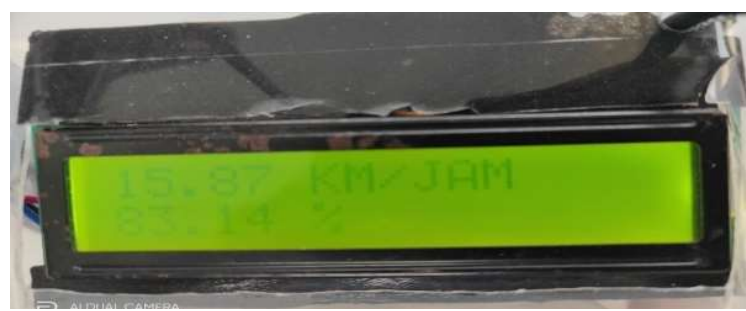

Gambar. 9 Tampilan keseluruhan sistem pada LCD

\section{Alur Proses}

\subsection{Perancangan Perangkat Keras}

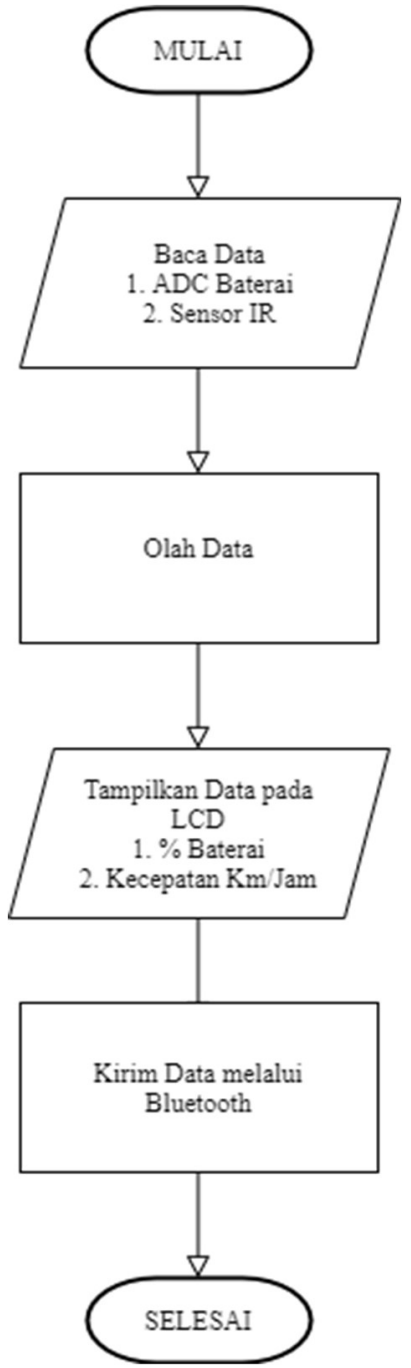

Gambar. 10 Perancangan perangkat keras 
Alur proses perangkat keras dimulai dengan pembacaan ADC dengan mikrokontroler dan sensor inframerah dengan $\operatorname{lm} 393$ lalu data yang didapat diolah pada mikrokontroler setelah itu data yang sudah terolah ditampilkan pada LCD berupa persentase baterai dan kecepatan yang sudah diubah $\mathrm{ke} \mathrm{Km} / \mathrm{jam}$ lalu dikirim melalui bluetott

\subsection{Perancangan Perangkat Lunak}

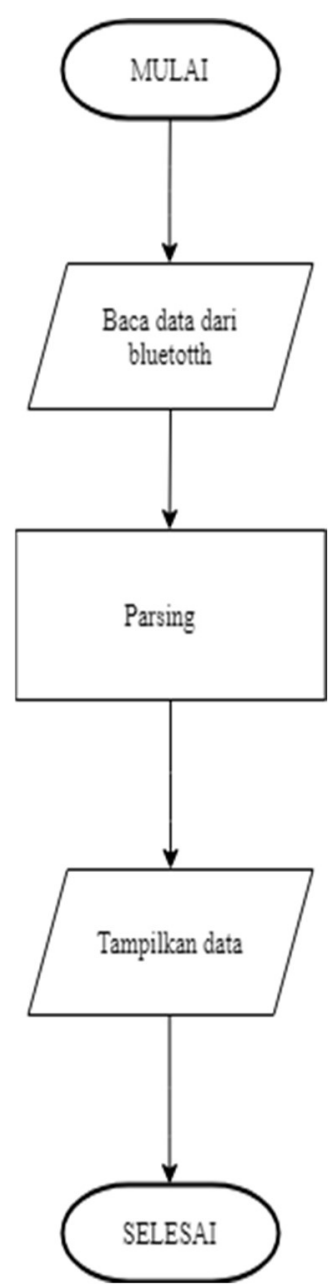

Gambar. 11 Perancangan perangkat lunak

Alur proses perancangan perangkat lunak dimulai dengan pembacaan data yang sudah dikirim melalui bluetooth HC-05 namun data tersebut masih menjadi satu kemudian data tersebut diparsing atau dibedakan yaitu data kecepatan dan data persentase baterai lalu ditampikan melalui HP android. 


\subsection{Skematik Rangkaian Sistem}

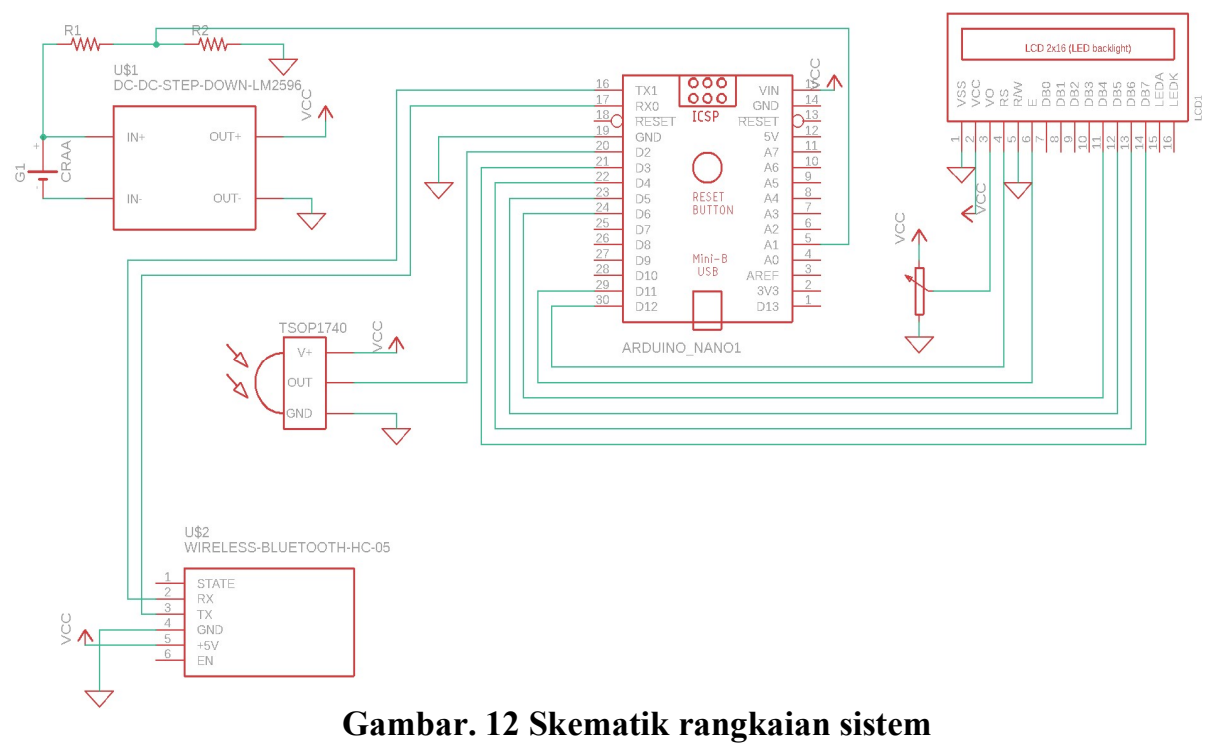

Skematik rangkaian pada monitoring kapasitas baterai dan kecepatan laju skuter listrik berbasis android. Dapat diketahui bahwa :

A. Tegangan diambil dari baterai yang ada pada skuter sebagai power suplay.

B. Tegangan diturunkan menggunakan modul regulator step down LM2596.

C. Mikrokontroler yang digunakan adalah arduino nano.

D. Baterai pada skuter dihubungkan pada rangkaian pembagi tegangan dengan masingmasing resistor sebesar $15 \mathrm{k} \Omega \mathrm{dn} 1,1 \mathrm{k} \Omega$.

E. Output dari pembagi tegangan dihubungkan dengan pin A1.

F. Sensor ir dihubungkann dengan pin D2.

G. LCD 16X2 dihubungkan dengan pin arduino dengan konfigurasi

- RS pada LCD dengan pin D12

- E pada LCD dengan pin D11

- DB4 pada LCD dengan pin D6

- DB5 pada LCD dengan pin D5

- DB6 pada LCD dengan pin D4

- DB7 pada LCD dengan pin D3

H. Bluetooth HC05 dihubungkan dengan pin arduinodengan konfigurasi

- RX pada bluetooth dengan TX arduino

- TX pada bluetotth dengan RX arduino

\section{Hasil dan Pembahasan}

Pengambilan data ini dilakukan di jalan trunojoyo mulai dari pertigaan kampus hingga Pelabuhan timur (peltim). Dan pada saat pengambilan data ini beban orang yang mengendarai adalah 55, 65, 69, 85 dan $92 \mathrm{~kg}$.

Di bawah ini beberapa contoh tabel pengambilan data yang sudah dilakukan 
Tabel 4 - Tabel persentae baterai dengan berat badan $55 \mathrm{~kg}$

\begin{tabular}{|c|c|c|}
\hline $\begin{array}{c}\text { Baterai } \\
(\%)\end{array}$ & Jarak (meter) & $\begin{array}{c}\text { Kecepatan } \\
(\mathbf{K m} / \mathbf{h})\end{array}$ \\
\hline 100,00 & 0,00 & 0,00 \\
\hline 100,00 & 52,33 & 3,14 \\
\hline 100,00 & 102,35 & 3,00 \\
\hline 100,00 & 150,82 & 2,91 \\
\hline 100,00 & 200,99 & 3,01 \\
\hline
\end{tabular}

Tabel 5 - Tabel persentae baterai dengan berat badan $65 \mathrm{~kg}$

\begin{tabular}{ccc}
\hline $\begin{array}{c}\text { Baterai } \\
\mathbf{( \% )}\end{array}$ & Jarak (meter) & $\begin{array}{c}\text { Kecepatan } \\
\mathbf{( K m / h )}\end{array}$ \\
\hline 100,00 & 350,76 & 3,01 \\
99,99 & 401,67 & 3,05 \\
99,88 & 450,88 & 2,95 \\
99,75 & 502,23 & 3,08 \\
99,43 & 552,42 & 3,01 \\
\hline
\end{tabular}

Tabel 6 - Tabel persentae baterai dengan berat badan $69 \mathrm{~kg}$

\begin{tabular}{ccc}
\hline $\begin{array}{c}\text { Baterai } \\
\mathbf{( \% )}\end{array}$ & Jarak (meter) & $\begin{array}{c}\text { Kecepatan } \\
\mathbf{( K m / h )}\end{array}$ \\
\hline 82,92 & 1450,59 & 2,93 \\
80,60 & 1501,76 & 3,07 \\
78,19 & 1551,86 & 3,01 \\
75,76 & 1602,39 & 3,03 \\
73,18 & 1651,08 & 2,92 \\
\hline
\end{tabular}

Tabel 6 - Tabel persentae baterai dengan berat badan $85 \mathrm{~kg}$

\begin{tabular}{|c|c|c|}
\hline $\begin{array}{c}\text { Baterai } \\
(\%)\end{array}$ & $\begin{array}{c}\text { Jarak } \\
\text { (meter) }\end{array}$ & $\begin{array}{c}\text { Kecepatan } \\
(\mathrm{Km} / \mathbf{h})\end{array}$ \\
\hline 73,50 & 1552,33 & 3,04 \\
\hline 70,85 & 1601,71 & 2,96 \\
\hline 68,18 & 1651,19 & 2,97 \\
\hline 65,62 & 1701,98 & 3,05 \\
\hline 63,28 & 1751,39 & 2,96 \\
\hline
\end{tabular}


Tabel 7 - Tabel persentae baterai dengan berat badan $92 \mathrm{~kg}$

\begin{tabular}{ccc}
\hline $\begin{array}{c}\text { Baterai } \\
\mathbf{( \% )}\end{array}$ & Jarak (meter) & $\begin{array}{c}\text { Kecepatan } \\
(\mathbf{K m} / \mathbf{h})\end{array}$ \\
\hline 52,82 & 2301,30 & 3,02 \\
52,26 & 2352,44 & 3,07 \\
51,70 & 2400,63 & 2,89 \\
51,14 & 2452,11 & 3,09 \\
50,62 & 2502,19 & 3,01 \\
\hline
\end{tabular}

Berikut adalah tampilan grafik dari kelima data tabel diatas.

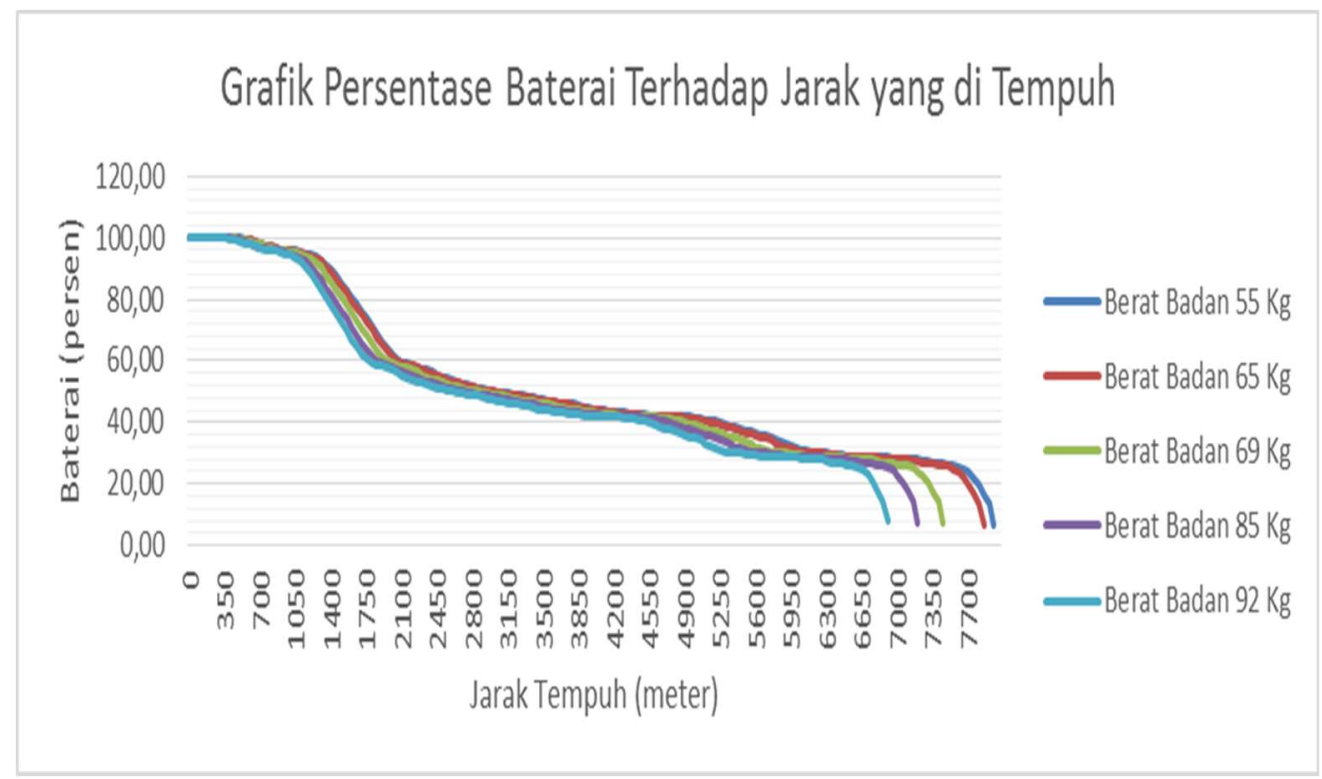

Gambar. 13 Grafik hasil percobaan

Pada grafik diatas dapat diketahui bahwa pada kilometer 0 - 1000 baterai menurun landai, pada kilometer 1000 - 1900 baterai menurun drastis dikarenakan jalanan terdapat tanjakan, pada kilometer 1900 - 4900 baterai menurun sedikit demi sedikit dikarenakan jalanan tidak rata atau jalanan berlubang, pada kilometer 4900 - 6700 baterai kembali menurun sedikit drastis dikarenakan jalanan terdapat tanjakan namun tidak curam, pada kilometer 6700 - 7900 baterai menurun drastis karena pengaruh tegangan drop. Berikut tampilan GUI pada android. 


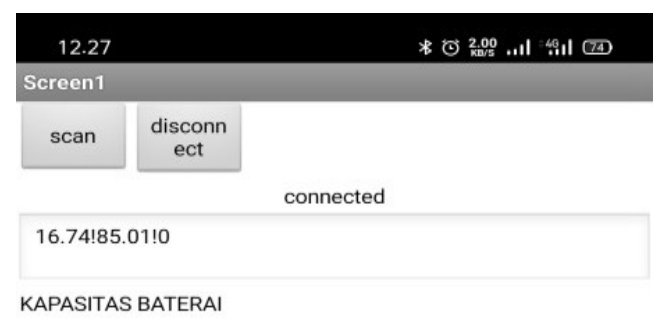

\subsection{1}

KECEPATAN

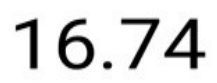

$\mathrm{Km} / \mathrm{Jam}$

\section{Gambar. 14 Tampilan Gui dan data pada android}

Pada tampilan GUI diatas berisi button scan yang berfungsi untuk mendeteksi bluetooth, dan button disconnect yang berfungsi untuk memutuskan koneksi bluetooth. Dibawah 2 button tersebut, terdapat indikator yang berfungsi menunjukkan bahwa bluetooth handphone telah terkoneksi dengan bluetooth yang ada pada skuter listrik. Kemudian, dibawah indikator terdapat kolom data yang berisi data kecepatan dan persentase baterai yang belum terparsing. Dibawah kolom tersebut terdapat 2 data yang sudah terparsing yaitu data kecepatan dan data persentase baterai saat itu.

\section{Kesimpulan}

Berdasarkan pengujian pada sistem yang telah dirancang bangun. Sistem dapat menunjukkan bahwa sistem mampu menampilkan data ADC yang telah dikonversikan menjadi persentase baterai, data sensor inframerah yang telah dikonversikan menjadi $\mathrm{km} / \mathrm{jam}$, dan data-data tersebut dapat ditampilkan pada LCD lalu dikirim melalui bluetooth ke android.

Skuter ini memerlukan waktu pengisian baterai yaitu 4 - 5 jam. Dalam keadaan baterai $100 \%$ - $0 \%$ Skuter mampu melaju hingga $20 \mathrm{~km} / \mathrm{jam}$, jarak yang dapat ditempuh oleh skuter ini adalah $7 \mathrm{~km}$. Namun, terdapat tegangan drop di setiap pengambilan data yang dilakukan, yaitu mulai baterai $25 \%$. 


\section{Ucapan Terima Kasih}

Terima kasih kepada ITN (Institut Teknologi Nasional) Malang dalam membantu menerbitkan jurnal saya yang berjudul monitoring kapasitas baterai dan kecepatan laju skuter listrik berbasis android.

\section{Daftar Pustaka}

Ilyasa, Y. B., Ulum, M., \& Ibadillah, A. F. (2020). PROSES PENGUKURAN PEMBUATAN BAJU. 03(1), 1-4

Ulum, M., Rozi, F., \& Ibadillah, A. F. (2020). Signal Classification and Electromyography (EMG) Instrumentation Design as Basic Electronic Control System. Journal of Physics: Conference Series, 1569(3). https://doi.org/10.1088/17426596/1569/3/032081

A. Nuryaman, E. Mulyana, and R. Mardiati, "Rancang Bangun Prototipe Alat Pengukur Kecepatan Kendaraan Dengan Sensor Infra Merah," Semin. Nas. Tek. Elektro, vol. 22, pp. 1516, 2017.

A. Giyantara, V. Mudeng, R. Ramadhani, and R. Wulandari, “Analisis Rangkaian Full Wave Rectifier dengan Filter Kapasitor, Pembagi Tegangan, Buffer dan Penguat Differensial pada Sensor Arus," SPECTA J. Technol., vol. 3, no. 2, pp. 1-9, 2019, doi: 10.35718/specta.v3i2.44.

O. M. Sinaulan, "Perancangan Alat Ukur Kecepatan Kendaraan Menggunakan ATMega 16," J. Tek. Elektro dan Komput., vol. 4, no. 3, pp. 60-70, 2015.

C. Rajini, R. Baiti, N. Domala, and E. B. Kumar, "Android Application based Speed and Direction Controlling of DC Motor using Bluetooth," vol. IX, no. V, pp. 3245-3251, 2020.

R. K. Megalingam, V. Rangan, S. Krishnan, and A. B. Edichery Alinkeezhil, "IR Sensor-Based Gesture Control Wheelchair for Stroke and SCI Patients," IEEE Sens. J., vol. 16, no. 17, pp. 6755-6765, 2016, doi: 10.1109/JSEN.2016.2585582.

S. Da Silva Carvalho, S. M. Ahsanuzzaman, and A. Prodic, "A low-volume multi-phase interleaved DC-DC converter for high step-down applications with auto-balancing of phase currents," Conf. Proc. - IEEE Appl. Power Electron. Conf. Expo. - APEC, vol. M, pp. 142148, 2017, doi: 10.1109/APEC.2017.7930685.

A. D. B. Sadewo, E. R. Widasari, and A. Muttaqin, "Perancangan Pengendali Rumah menggunakan Smartphone Android dengan Konektivitas Bluetooth," J. Pengemb. Teknol. Inf. dan Ilmu Komput., vol. 1, no. 5, pp. 415-425, 2017. 